\title{
The legacy of the Haldde Observatory
}

\author{
Asgeir Brekke \\ Troms $\varnothing$ Geophysical Observatory, UiT The Arctic University of Norway, Troms $\varnothing$, Norway \\ Correspondence: Asgeir Brekke (asgeir.brekke@uit.no)
}

Received: 24 October 2020 - Accepted: 17 November 2020 - Published: 14 January 2021

\begin{abstract}
A historical review of the establishment of the Haldde Observatory in Bossekop, Kaafjord, Finnmark, in northern Norway is presented together with some of the scientific outcomes of the efforts and the aftermath of this enterprise that led to the establishment of the University of Troms $\varnothing$ in 1968 and finally the inauguration of the Haldde Observatory as a historic site by the European Physical Society in 2018.
\end{abstract}

\section{Bossekop in Finnmark, Norway - a resort for auroral studies}

When the French king Louis Philippe I (1773-1850) sent out the corvette La Recherche for a cruise to Spitzbergen (now known as Svalbard) and Faeroe Islands in the years 18381840, a team under the leadership of the physicist Auguste Bravais (1811-1863) was set a shore in Bossekop in Finnmark (Fig. 1), Norway, to observe the aurora and the Earth's magnetic field (Lottin et al., 1840; Knutsen and Posti, 2002). This initiative, in a remarkable way, opened the gate to Finnmark as a scene for international auroral research.

During the First International Polar Year 1882-1883, Norway contributed by establishing a meteorological observatory at Bossekop initiated by professor Henrik Mohn (18351916), the first director of the Norwegian Meteorological Institute. At the same time the Danish teacher Sophus Tromholt (1851-1896) installed himself with a private station at Kautokeino about $107 \mathrm{~km}$ away, to measure by triangulation the height of the aurorae. He obtained a mean altitude of $113 \mathrm{~km}$ of altogether 18 aurorae (Tromholt, 1885; Moss and Stauning, 2012).

In 1892 the German physicist Martin Brendel (18621939) went to Bossekop and succeeded as the first known person to have taken a photo of the northern lights. By the end of the 19th century, Bossekop was then well established as a strategic resort for auroral research (Brekke and Lynne Hansen, 1997).

\section{The aurora - a meteorological phenomenon}

At this time the height of the aurora was a challenging question to many scientists as there were rumours among the inhabitants of Finnmark that the northern lights were seen all the way down to the sea level. The French scientist Alfred Angot (1848-1924) discussed in 1897, with reference to some observations made by Bravais in Bossekop, the relationship between cirrus clouds and auroral arcs and bands and maintained that the northern lights were a meteorological phenomenon (Angot, 1897).

In the 1890s there were many serious accidents with fishing boats in the North Sea and many fishermen were lost. There had been a long tradition of obtaining weather predictions in the northern lights, but there was still a demanding need for an improved weather forecast system along the Norwegian coast. Linking auroral research as a remedy for improving the weather forecast became therefore a legitimate argument for establishing an auroral observatory in the north of Norway.

\section{The height of the northern lights was an open question}

In 1896 Kristian Birkeland (1867-1917) published a paper in which he proposed that the northern lights were created by cathode rays from the sun that were soaked in towards the Earth's atmosphere by the geomagnetic field and forced to move towards the Earth around the magnetic pole (Birkeland, 1896). The time seemed to be ready for optical triangulation of the auroral heights, and Birkeland decided to try 


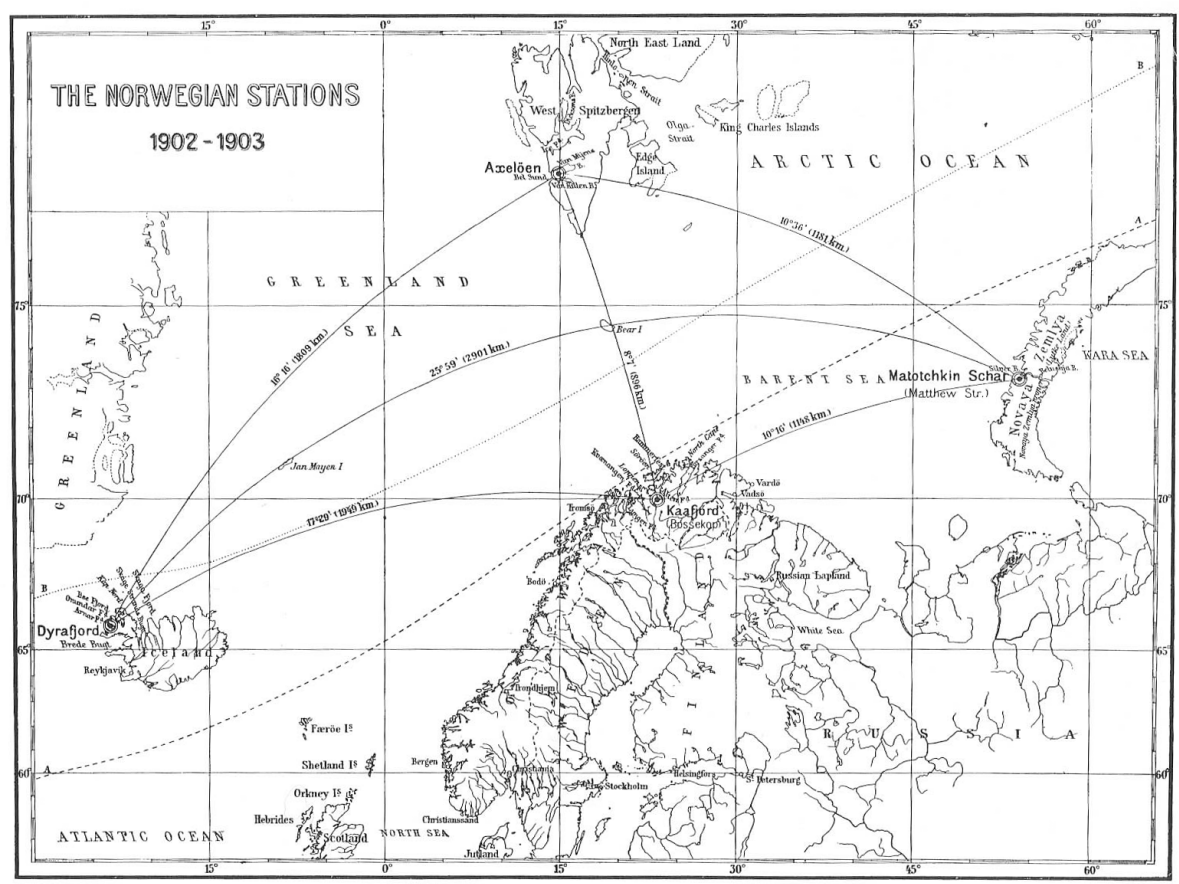

Figure 1. Map of Scandinavia with Bossekop (Kaafjord) marked at the centre (Birkeland, 1908).

it out. He applied to the Norwegian Government in 1898 for economic support to establish two small observatories: one at Haldde summit and the other at Talvik summit, two mountaintops about $3.4 \mathrm{~km}$ apart and $900 \mathrm{~m}$ above sea level close to Bossekop (Friedman, 2010).

One might wonder why Birkeland placed the two stations so close together when the British physicist Jon Dalton (1766-1844) already in 1828 mentioned that Henry Cavendish (1731-1810) in 1790 had measured the height of an auroral arc to be "between fifty-two and seventy-one miles", but he maintained that the observers used a too short of a baseline for the triangulation. "A base of at least forty or fifty miles seems necessary, where the object to be measured is generally neither steady or well defined." (Dalton, 1828).

It appears that Birkeland trusted neither Cavendish's nor Tromholt's work but rather leaned on the rumours among the laity and believed that the northern lights were a weather phenomenon. He assumed that the cathode rays that were present in the northern lights were capable of penetrating so deep into the atmosphere that they would affect the meteorological conditions, especially the creation of clouds. For this reason, he argued that it would be of interest to carry out a more thorough study of the electric phenomena that occurred in the somewhat higher layers of the atmosphere (Krogness, 1928).

Birkeland was appointed as professor at the University of Christiania (Oslo) in 1898 and obtained support from the Norwegian Government to construct the two observatories. In October 1899 he ascended, together with four assistants, to the Haldde Observatory, where they installed themselves with a multitude of instruments.

The expedition of 1899-1900 was furnished, inter alia, with self-registering barometers, and hygrometers, and also with apparatus for the photographic registration of the three components of terrestrial magnetism, and of the electric condition of the atmosphere. (Birkeland, 1908)

Between the Haldde and Talvik summits they installed a telephone line, and at each observatory they also mounted optical cameras for auroral triangulation.

Birkeland and two of his assistants stayed in the Haldde Observatory, while two other assistants installed themselves at the Talvik Observatory and had to frequently walk over to Haldde for provision.

Birkeland and his crew stayed in the mountains over the winter, but a few days before they were going to depart from the peak in late March 1900, two persons perished on their way up to Haldde in an avalanche that set a dramatic end to the expedition. One of the lost ones was Elias Boye (18781900), the junior of the team.

\section{The height measurements were a complete failure}

On the front page of the report that Birkeland published (Birkeland, 1901) based on the results from the expedition to Bossekop, there was a drawing made by Boye depicting the two observatories with Haldde in front (Fig. 2). In the 


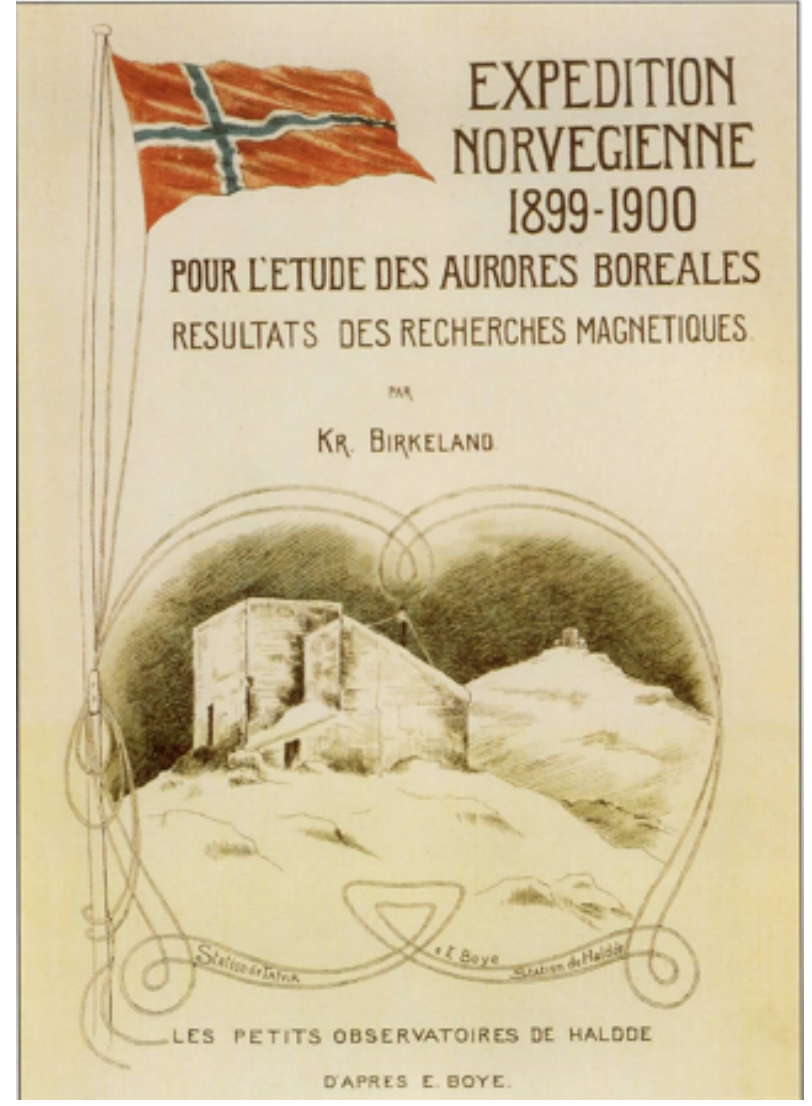

Figure 2. The front page of the report from the expedition to Haldde in 1899-1900 drawn by Elias Boye (Birkeland, 1901).

upper left corner of the picture there is a plain Norwegian flag illustrating the patriotic mark that Birkeland wanted to raise in front of his expedition. The turn of the 20th century was indeed a time of national pride for Norway when the Norwegian population was struggling for independence from Sweden. In 1896 Fridtjof Nansen (1861-1930) had returned back to Norway after a heroic journey into the high Arctic in an attempt to reach the North Pole. This lifted the self-esteem unprecedented by the Norwegian population into which Birkeland also wanted to put in his oars (Friedman, 2010).

In this report the optical observations of the northern lights and the triangulation experiment are hardly mentioned. The reason for this was that this part of the expedition was considered to be a failure, partly due to extreme weather conditions (Birkeland, 1908), but also due to a too short of a baseline between the observatories as well as insensitive photographic plates (Devik, 1971).

The report includes two main sections and an appendix. The first section describes weak and short periodic variations observed in the Earth's magnetic field at the same time at Haldde and in Potsdam, Germany. As these were most out- standing in the Haldde recordings, it indicated that the source of the variations was located in the polar region.

The second section compares strong variations in the three components of the Earth's magnetic field as observed simultaneously at Haldde and the observatories in Pavlovsk, Copenhagen, Potsdam, Paris, Greenwich and Toronto.

Based on his experience from the expedition to Haldde during the winter 1899-1900, Birkeland wrote the following:

I demonstrated namely, that certain well-defined magnetic perturbations that occurred over large portions of the earth might be naturally explained as the effect of electric currents, which, it might be supposed, in the polar regions flowed approximately parallel with the surface of the earth at heights of several hundred kilometres, and strengths of up to a million ampéres, if they could be measured by their effect as galvanic currents. These currents in the polar regions were well defined and greatly concentrated and often passed for the most part between two neighbouring stations, as, for instance, Bossekop and Jan Mayen, and in such a way that Bossekop lay quite on the one side of the current and Jan Mayen on the other; and the magnetic effect of the currents in the polar regions was infrequently as much as 20 times stronger than at Central Europe. The investigation of these phenomena would necessarily, of course, require simultaneous registrations of the magnetic elements at several uniformly equipped polar stations. (Birkeland, 1908)

In his summary of these observations he introduced a global current system across the Arctic region that resembles the conventional ion convection patterns that are so commonly used in modern literature about the current systems at high latitudes. The arrows, however, represent the motion of negative charges (Fig. 3) (Birkeland, 1901).

In the appendix Birkeland published some observations of experiments he performed with discharge tubes. Any discussion of the optical auroral observations was left out. As a matter of fact, Birkeland did not involve himself anymore in optical observations of the aurora but rather drew on his knowledge about the phenomenon from terrella experiments in the laboratory.

\section{Birkeland expanded his ground-based network}

Birkeland again applied to the Norwegian Government for financial support to establish a network of four stations in the Arctic through the winter 1902-1903 (Friedman, 2010). From the grants he obtained he installed one station at Axeløen in Spitzbergen, one at Dyrafjord on Iceland, one at Matochkin Shar at Novaya Zemlya, and one at the copper mine in Kåfjord, the latter forming the centre of the campaign. 


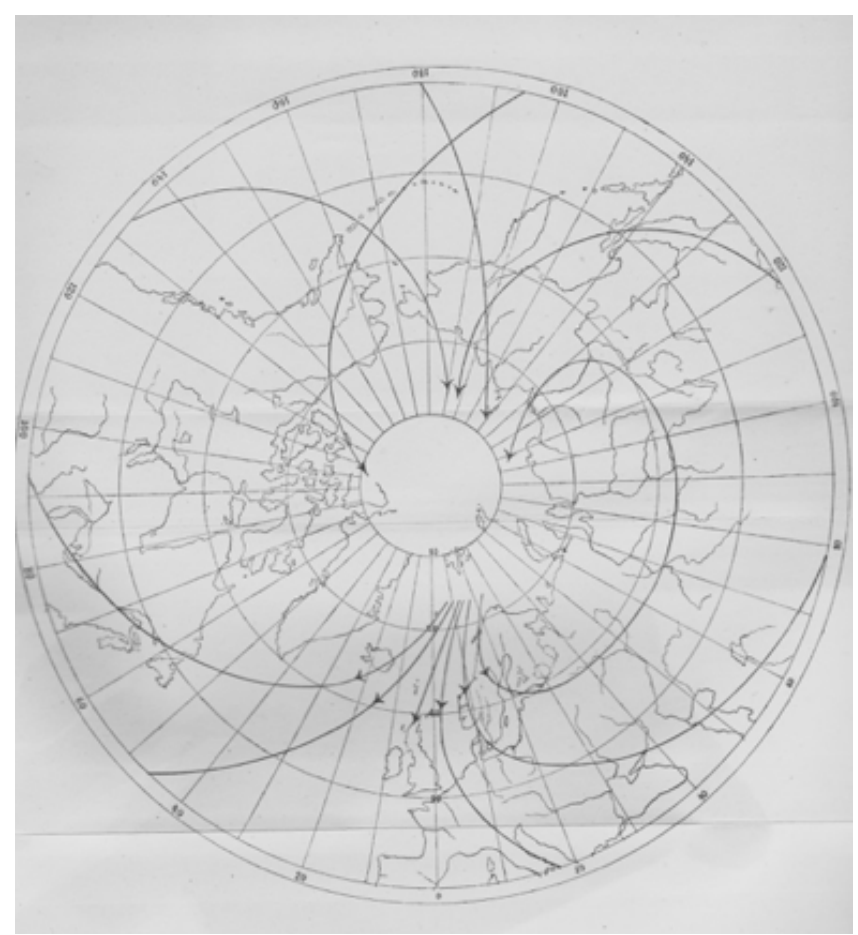

Figure 3. Convection systems of negative charges across the polar region according to Birkeland (1901).

Haldde was left out this time, and the observatory of Talvik was only in use for a few weeks in the summer of 1902.

The four stations were equipped with magnetometers as well as meteorological, atmospheric, and some astronomical instruments.

\section{A magnetic-meteorological observatory at Haldde}

The Haldde Observatory was abandoned for many years. In 1910, however, Birkeland and his assistant, Ole Andreas Krogness (1868-1934), ascended the mountain to observe Halley's Comet on 18-19 May. During his stay at the peak, Birkeland was so impressed by the site that after returning to Oslo he immediately applied to the government for support to build a permanent "magnetic-meteorological observatory" at Haldde to be operational for at least two solar cycles. In his application he argued that he had, during his expedition to Haldde, at the turn of the century, discovered an electrical connection between geomagnetism and meteorological phenomena as the air was ionized after strong magnetic storms. He maintained that this ionization was influencing the formation of clouds as well as the electric condition of the Earth (Devik, 1971). A committee appointed by the Faculty of Science and Mathematics at the University of Christiania (now Oslo) called into question whether there was any relation between magnetic storms and the weather but supported the idea of an observatory in the north of Norway. The Norwegian Meteorological Institute argued for building the obser-

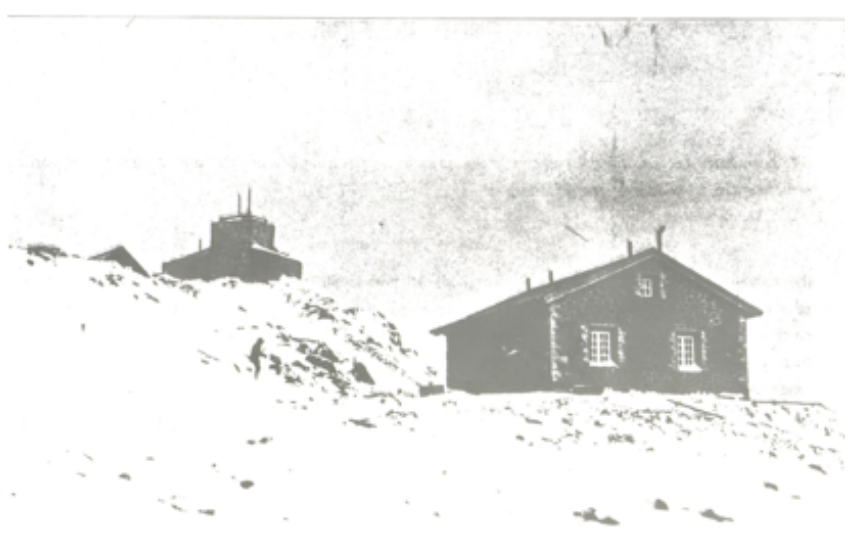

Figure 4. The observatory at Haldde in 1912 with "Borgen" in the back (Brekke, 1982).

vatory in Bossekop and not on the mountaintop of Haldde as a preferred place for improving the weather forecast in the north. Birkeland got what he wanted and was granted NOK 30000 to construct the observatory at Haldde as well as to obtain the necessary scientific equipment (Føyn, 1915).

In the autumn of 1912 a magnetic-meteorological observatory (Fig. 4) was ready at Haldde. It consisted of three rooms, and in October that year Krogness could move in together with his family, in addition to two assistants that were living in the original observation tower "Borgen" (Nielssen and Pettersen, 1993; Bunting and Jensen, 2018).

Professor Lars Vegard (1880-1963) went to Bossekop the same autumn to carry out spectroscopic observations of northern lights. During his visit he arranged together with Krogness to triangulate the height of the aurora by installing a camera in Bossekop in addition to the one already in place at Haldde $12.5 \mathrm{~km}$ apart. The cameras available were, however, not well suited for working in the very cold weather that they had to face. Krogness therefore set out to construct a new camera that made it possible to take six pictures in a row before the photographic plate had to be shifted in the workshop (Fig. 5). This type of camera was frequently in use by auroral scientists until the 1950s.

\section{Expanding the Haldde Observatory for meteorological purposes}

It was soon realized, however, that the extreme living conditions for the two assistants dwelling in "Borgen" were far from acceptable. The more than 10 -year-old stone walls were in bad condition and gave little shelter from the storms outside. When the two almost perished due to carbon monoxide from a leaking stove, they escaped down to the living quarter to share the rooms with the Krogness family.

The new building was not large enough for housing personnel for the meteorological engagement. Birkeland therefore again applied to the Norwegian Government for support; 

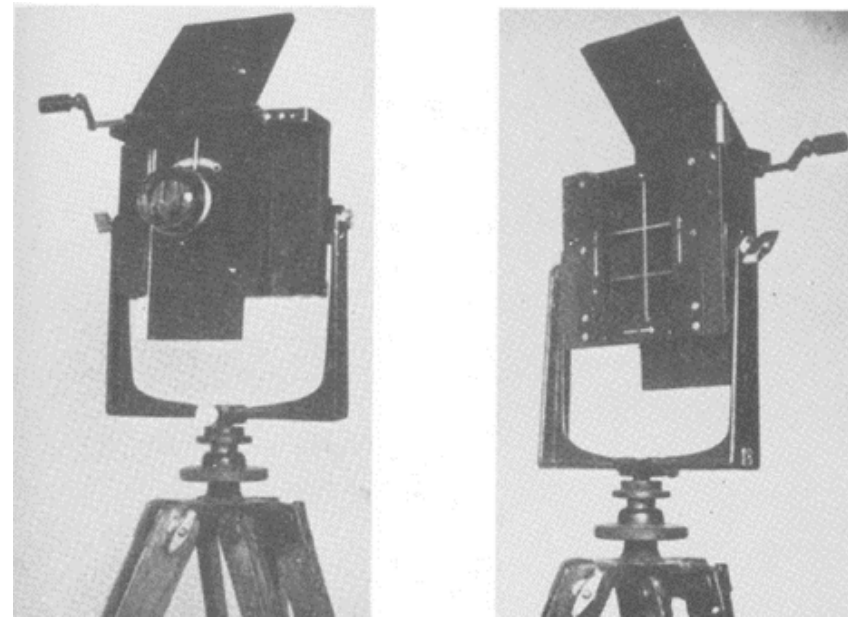

Figure 5. The auroral camera constructed by Krogness (Störmer, 1955).

with personal contributions and help from sponsors he could continue expanding his observatory. In 1915 the building was ready to house four families, and Olaf Devik (1886-1987) could move in with his wife to take up the work of improving the weather forecast in the north. The observatory had an $8 \times 18 \mathrm{~m}^{2}$ base, furnished with 15 rooms and a rather large room in the basement.

In addition to the main building there were also a technical workshop, the house for the magnetic registering, a wash house, and a bathhouse all connected by underground passages, as well as a hut for meteorological observations. There was a road all the way up to the top, but as this was impossible to be used during the winter for transport by horses, a telpher was also installed. Even a cow was brought to the top to provide milk for the seven children that grew up there, three of which were born on the top (Nielssen and Pettersen, 1993; Bunting and Jensen, 2018).

A $10 \mathrm{kV}$ transmission line was stretched from the power station in Kåfjord, supplying $50 \mathrm{~kW}$ to the observatory at Haldde as well as a double telephone line. There was also a smaller weather station set up at Bossekop.

Observations of the meteorological conditions were the main activity in the years from 1912-1918 when Krogness was in charge of the observatory. They recorded atmospheric temperature, pressure, humidity, and wind, as well as precipitation and sunshine. They also observed the atmospheric electricity as well as potential gradients, combined with necessary absolute measurements.

In order to improve their database, they contacted coastal steamers and installed barographs on board the ships. They also cooperated with Swedish and Russian meteorological stations in their work.

\section{A monsoon-like wind system}

Haldde was an exposed site weatherwise. Wind speeds of more than $50 \mathrm{~m} \mathrm{~s}^{-1}$ occurred rather frequently, and speeds larger than $70 \mathrm{~m} \mathrm{~s}^{-1}$ were not uncommon. Occasionally, during calm and clear weather days on Haldde they observed hurricane-like snowdrifts underneath the mountaintop.

Due to the very strong temperature differences, especially in wintertime, between the warm water in the Gulf Stream outside the coast and the strong Siberian frost in the inland, this is one of the stormiest regions on Earth. Therefore, it was argued that an observatory on Haldde would be extremely favourable for studies of dynamic meteorology. Even though they obtained a good view of the main characteristics of the wind system in northern Norway, it turned out to be a more difficult task to forecast these land storms in a satisfactory way (Krogness, 1915).

They interpreted their observations with reference to the existing models presented by Nils Gunnar Ekholm (18481923), a Swedish meteorologist and polar explorer who lead the Swedish expedition to Spitzbergen in 1882-1883 and became the founder of the Swedish storm warning system. Krogness and Devik concluded that their observations strongly supported Ekholm's predictions of strong offshore winds close to the surface and return winds at larger altitudes:

Man hat mit anderen Worten die ebengeschilderte Strömung, einem horizontalen Wirbel mit einer so niedrig gelegenen Achse, dass Haldde sich in der oberen Gegenströmung befindet. [One has, in other words, the stream, as already mentioned, a horizontal eddy with axis lying so low that Haldde is situated in the upper counterstream.] (Krogness, $1928)^{1}$

They maintained that a wind system of emphatic monsoon character played a fundamental role in driving the remarkable winds that often occurred in the north during the winter.

By comparing their observations with the observations done by the Swedish oceanographer Johan Sandström (1874-1947) in Lapland, Krogness and Devik could establish the existence of this wind system (Krogness and Devik, 1917). It was also pointed out by them that Sandström probably was right in his assumption that this wind system was of great importance in relation to the peculiar wind systems that often occurred in the north and brought about sudden and severe off-land wind storms that baffled all the rules for ordinary prognoses (Krogness and Devik, 1917).

\footnotetext{
${ }^{1}$ Ole Andreas Krogness and Hilding Köhler were invited by Jahrbericht des Sonnblick-Vereines für das Jahr 1926 to write up resumes of their scientific outcome of the Haldde expeditions.
} 


\section{Observations of atmospheric electricity}

One of the reasons for establishing an observatory on a mountaintop about $1000 \mathrm{~m}$ a.s.l. underneath the auroral zone in northern Norway was to investigate whether the cathode rays forming the northern lights had any impact on the atmospheric electricity at these heights in this region. According to Birkeland's idea, the northern lights were due to very hard corpuscular radiation, a radiation that, according to him, would be considerably harder than any known kind of radiation at that time. He therefore thought that an investigation of the atmospheric electricity at a level of about $1000 \mathrm{~m}$ above ground could give some interesting information regarding this question. It turned out, however, to be rather difficult to carry out successful registrations during the harsh climatic conditions prevailing on the mountaintop. Krogness and Devik were therefore not able to find any trace of direct influence from the northern lights:

Auch ist es uns nicht gelungen, irgendeine mittelbare Wirkung dieser Art festzustellen. Besonders sei erwähnt, dass wir keine Anhaltspunkte für die Annahme haben, dass die Nordlichtstrahlen Kondensation und Wolkenbildungen in den höchsten Schichten der Atmosphäre hervorrufen können, wie früher von mehreren Verfassern behauptet worden ist. Auch Birkeland war zu einer solchen Auffassung geneigt und dachte sich die Möglichkeit, dass man mit luftelektrischen Beobachtungen als Zwischenglied vielleicht eine Verbindung zwischen Nordlichterscheinungen und magnetischen Stürmen einerseits und meteorologischen Erscheinungen andererseits finden könnte. [We have not succeeded in establishing any direct effect of this kind. It must be especially mentioned that we have no facts supporting the assumption that the rays of the northern lights can give rise to condensation and creation of clouds in the uppermost layers of the atmosphere, as is alleged by several authors. Birkeland also leaned to such an opinion that by exploiting observations of the electricity in the air as a link, it could be possible to find the connection between the occurrence of northern lights and magnetic storms on one side and meteorological phenomena on the other.] (Krogness, 1928)

On the other hand, they sometimes observed some abnormal behaviour of the atmospheric electricity during strong polar storms and hurricanes that they believed could be of interest for future weather forecasting. By accident they also observed a strong electric charge building up on a telephone line about $25 \mathrm{~km}$ long between Hammerfest and Kårhavn the day before a very strong hurricane occurred that brought about several accidents at sea. Krogness believed that this was a phenomenon that had never been observed before and

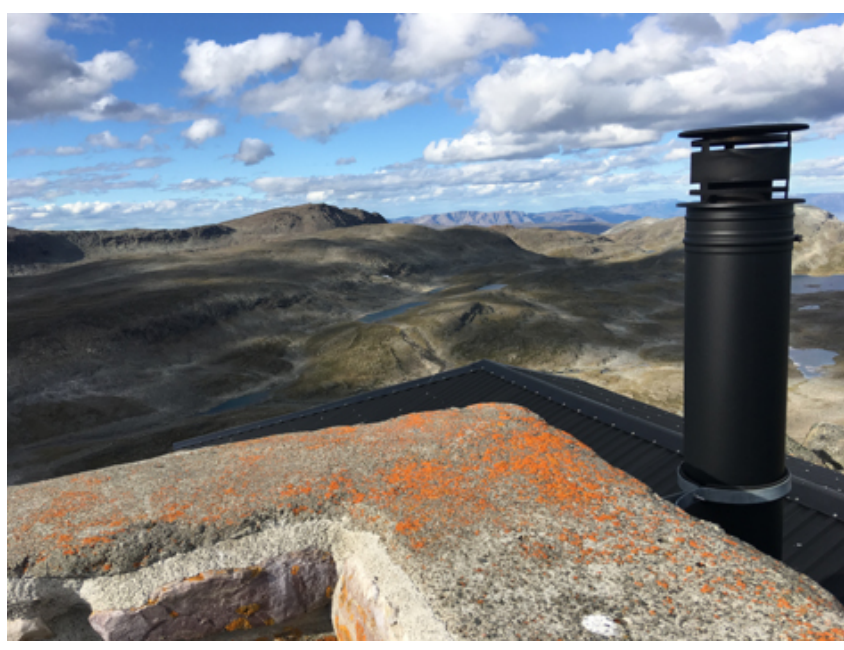

Figure 6. A wide view from the top of the Haldde Observatory (photo: Asgeir Brekke, 2018).

hopefully could be used in future storm predictions (Krogness, 1915).

\section{Expanding the network of magnetic observations}

Birkeland had argued for an expansion of the number of magnetic observatories in the polar region in order to investigate the magnetic perturbations that were "infrequently" observed to be 20 times stronger in Bossekop and Jan Mayen than at lower latitudes. Krogness, who had been an assistant of Birkeland and written a large part of the luxurious book The Norwegian Aurora Polaris Expedition 1902-1903 (Birkeland, 1908), followed up on Birkeland's idea and found a need for more magnetic observatories to the south of the auroral zone. In September 1915 he applied to the Norwegian Government for support, where he in particular mentioned the lacuna between the observatory at Haldde and the observatories at Rude Skov in Denmark and Polkovo in Petrograd (St. Petersburg), Russia. He argued for an observatory more central in Norway, in the Dovre region, and contacted the astronomer Sigurd Enebo (1866-1946), who lived in Dombås and became world famous for his observation in 1912 of a supernova (Bentdal, 2012). At the end of December 1915, the new observatory in Dombås was installed and the first magnetic recordings appeared on 1 April 1916.

From his pavilion at Haldde, Krogness corresponded with Enebo and gave him advice on how to construe the magnetograms by sending him illustrations of some typical recordings that Krogness himself was interested in (Krogness, 1982). 


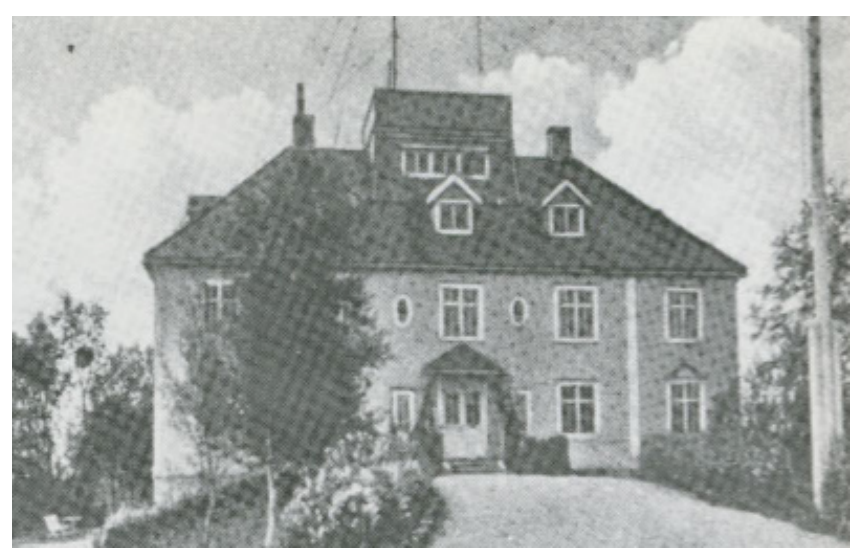

Figure 7. The geophysical institute in Troms $\emptyset$ was inaugurated in 1919 (photo: Høegh, 1971).

\section{A view from the top}

At their leisure Krogness and Devik had ample time to reflect on their future role in science as well as the well-being of their families. Inspired by the wide view from the top (Fig. 6), they dreamed about founding an academic institution in order to improve the geophysical knowledge in the high north and started to look for a more suitable place as they soon realized that the observatory at Haldde was unfit for future research work. Krogness in hindsight wrote the following:

Es bestand nie die Absicht, daß die regelmäßige, künftige meteorologische und magnetische Arbeit in nördlichen Norwegen dem HalddeObservatorium obliegen sollte. Dazu sind die Lebensverhältnisse dort oben $\mathrm{zu}$ schwierig. [It was not the intention that the Haldde Observatory in northern Norway be devoted in the future to regular meteorological and magnetic work. In that respect, the living conditions up there were too difficult.] (Krogness, 1928)

In the summer of 1915 Krogness and Devik went to a science meeting in Stockholm where they met with Johan Sandström and Bjørn Helland-Hansen (1877-1957), both scholars of the Bergen School of Meteorology established by Professor Vilhelm Bjerknes (1874-1947). Here they agreed to work to set up a geophysical institute in Bergen and Troms $\varnothing$ (Devik, 1971).

Devik met in November 1916 with the prime minister of Norway in Oslo, who promised that if the citizens of Troms $\varnothing$ could provide a site as well as a building, the government would grant financial support for the running costs as long as regular weather forecasts in northern Norway could be guaranteed. Krogness and Devik contacted the middle-class people in Troms $\varnothing$ and arranged a meeting with them in December 1916, and a committee was soon set up to collect enough

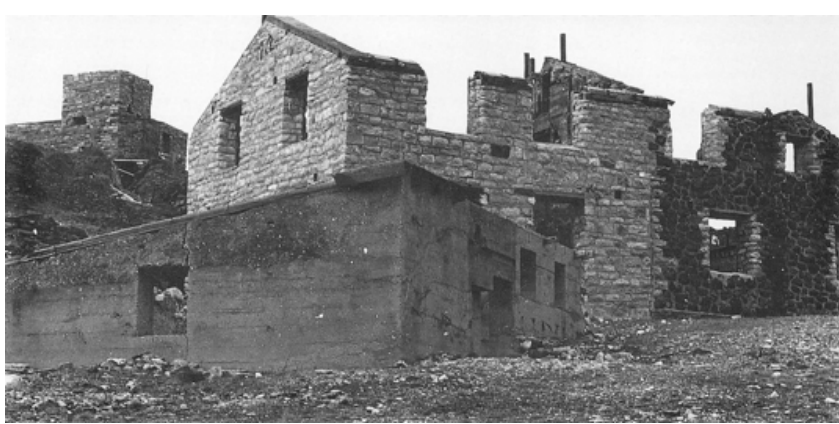

Figure 8. The ruins of Haldde in 1973 (Nielssen and Pettersen, 1993).

money to construct a building for the institute. The Norwegian Parliament decided the following on 15 June 1917: "The Parliament agrees to establish a geophysical institute in Troms $\varnothing$ that includes the magnetic-meteorological observatory at Haldde." (Devik, 1971).

Krogness and Devik left Haldde midsummer 1918 and moved into the new building of the geophysical institute, "Geofysen" by tradition, in Troms $\varnothing$ in July the same year (Fig. 7). Krogness was appointed as head of the institute with special responsibility for magnetic observations, while Devik was given the responsibility of preparing to establish a weather forecast system in northern Norway. The Swedish physicist Hilding Köhler (1888-1982) was appointed as head of the Haldde Observatory from October 1918; inspired by the Austrian meteorologist Max Margules (1856-1920), he, by installing several specially designed huts for thermographs and anemometers in the area, continued the studies initiated by Krogness of the dynamic weather conditions around the mountaintop. Due to the difficulties in keeping the cables on the ground mended, he had to give up these experiments already in 1920. Köhler also engaged in studies on the condensation process in air by measuring the frost deposits in fog. He, also inspired by the Austrian meteorologist Victor von Conrad (1876-1962), measured the magnitude of waterdrops by chemical analysis (Köhler, 1928).

Köhler was in charge of the observatory until it was closed down in 1926 due to economic difficulties as stated by Krogness:

Das Observatorium war von vornherein für einen Zeitraum von zwei Sonnenfleckperioden geplant. Ökonomische Schwierigkeiten veranlaßten inzwischen, daß man den regelmäßigen Betrieb etwas früher - im September 1926 - abschließen mußte. [The observatory was planned beforehand for a period of two solar cycles. Financial difficulties in the meantime led to an earlier closing of the regular drift - in September 1926.] (Krogness, 1928) 


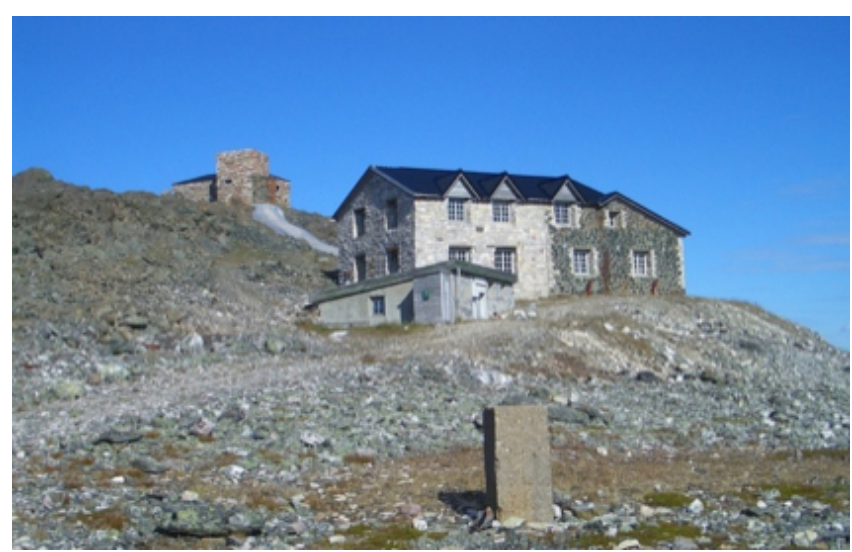

Figure 9. The Haldde Observatory in August 2018 (photo: Asgeir Brekke, 2018).

Krogness was hoping that there would be future activities on Haldde, as he wrote the following:

Doch werde die Häuser instand gehalten, und es ist die Absicht, daß die Anlage auch künftig für Beobachtungen geophysikalischer Expeditionen dienen soll. Vielleicht wird die Anlage auch später für den Wetterwarnungsdienst verwendet und ein Betrieb im kleineren Maßstabe wieder aufgenommen. [Still the houses will be kept in shape, and it is the intention that the buildings will serve for observations of geophysical expeditions in the future. Probably the construction will also later be used for weather warning services and a smaller staff will be further maintained.] (Krogness, 1928)

The expectations of Krogness were never met as the doors of Haldde were finally closed, but the houses as well as installations were kept in shape until the last days of the Second World War when they were demolished (Fig. 8).

\section{The spirit of Haldde prevailed}

When Vegard obtained a grant from the National Science Foundation in 1919 to buy new and more advanced spectrographs for observations of auroral emissions, he went to Haldde and concluded that the observatory was not well suited for such expeditions, and in 1920 he turned to the Troms $\varnothing$ Geophysical Observatory and installed his spectrograph at an observing platform situated on the top of the roof. But alas, the space soon became too small, and Professor Lars Vegard, being a world-renowned scientist for his studies on the auroral spectrum, applied in 1925 to The Rockefeller Foundation for economical support to build a special auroral observatory at the top of the island of Troms $\varnothing$. As the Norwegian Government established an organization called the Norwegian Institute for Cosmic Physics (NIKF) to warrant the

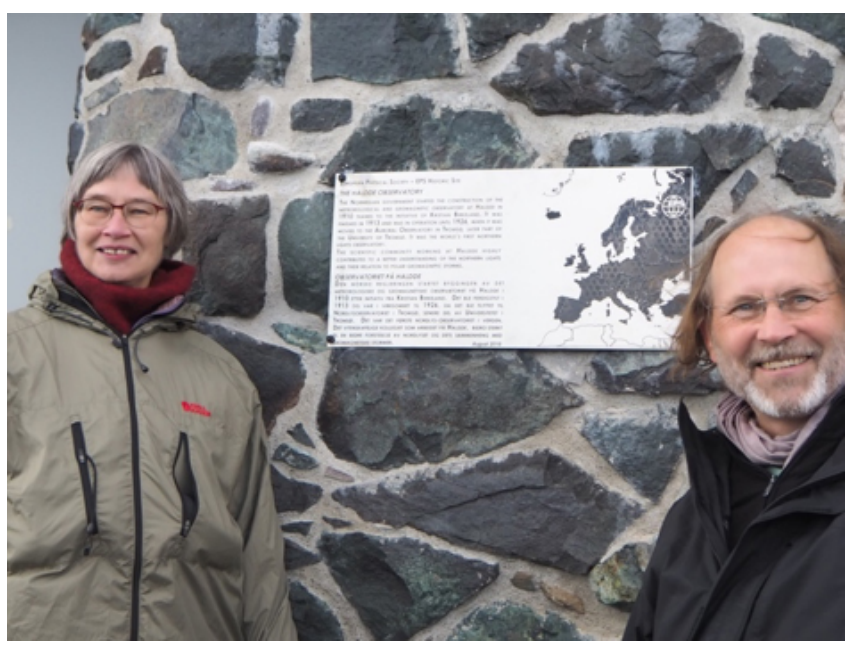

Figure 10. Professor Åshild Fredriksen from the University of Troms $\varnothing$, UiT The Arctic University of Norway and the Secretary General of EPS David Lee in front of the plaque unveiled at the stonewall of the old observatory on Haldde (photo: Asgeir Brekke, 2018).

running costs of this observatory, Vegard obtained the grant he asked for from The Rockefeller Foundation and the observatory was ready in 1928.

In the meantime, a proposal was launched to establish a university for northern Norway in Troms $\emptyset$, and enthusiastic citizens of the town applauded the idea. Krogness arranged a committee to work for a closer scientific cooperation between the academic institutions in town, i.e. the Troms $\varnothing \mathrm{Mu}-$ seum, the auroral observatory, and the geophysical institute, while the long-term motivation was to establish a university in Troms $\varnothing$. Nothing much happened concerning the university through the difficult days of the economic crises in the 1930s and the following years of the Second World War. As Norway struggled through the aftermath of the war, the idea for a university in the north of Norway surfaced again among the central politicians. The rationale was to stop the young people from leaving the north of Norway to the more central cities in the south by educating them in their local area, and there was especially a need for improving the healthcare by educating more medical practitioners locally. In March 1968 the central government decided to establish a university in Troms $\varnothing$, and a planning committee was set up in which Professor Anders Omholt (1926-1917), who had been the director of the auroral observatory from 1966 to 1968, and Professor Olav Holt, the director of the observatory at the time, both were appointed to the committee (Fulsås, 1993). Holt was also appointed as chairman of a subcommittee to plan for the science department of the new university, and Asgeir Brekke was appointed as his secretary. The science group that could track their scientific forebears back to the community at Haldde certainly had a strong impact on the planning process. The University of Troms $\varnothing$ (UiT) arose like Phoenix 
from the ashes, and the legacy of Haldde was well taken care of.

\section{The aftermath}

UiT The Arctic University of Norway, formerly the University of Troms $\varnothing$, and the local authority of the Alta region have made efforts to refurbish the Haldde Observatory in honour of the pioneers that worked there (Fig. 9).

On 26 August 2018 the observatory on the Haldde mountain was inaugurated as a historic site by the European Physical Society (EPS) (Fig. 10).

Data availability. No data sets were used in this article.

Competing interests. The author declares that there is no conflict of interest.

Special issue statement. This article is part of the special issue "History of geophysical institutes and observatories". It is not associated with a conference.

Acknowledgements. The author is indebted Chris Hall and Magnar Gullestad Johnsen, Troms $\varnothing$ Geophysical Observatory, for their help. Also, thanks to the referees for their enlightening advice.

Review statement. This paper was edited by Kristian Schlegel and reviewed by Per Pippin Aspaas and Eivind Thrane.

\section{References}

Angot, A.: The Aurore Borealis, New York, D. Appleton And Company, 104-119, 1897.

Bentdal, G. (Ed.): En himmelrommets Fyrvokter, Snøhetta forlag as, Dombås, Norway, 2012.

Birkeland, K.: Sur les Rayons Cathodiques sous l'Action de Forces Magnétique Intenses, Archives des Sciences Physique et Naturelle, T. 1, Archives des Sciences Physique et Naturelle, 4éme période, Vol. 1, Geneve, 497-512, 1896.

Birkleland, K.: Expedition Norvegienne 1899-1900 pour lètude des aurores boreales. Resultats des recherches magnetique, Skrifter Videnskabsselskabet i Christiania, I, Mat.-Nat. Klasse, Christiania, 1-81, 1901.

Birkeland, K.: The Norwegian Aurora Polaris Expedition 19021903, Vol. 1, On the cause of magnetic storms and the Origin of Terrestrial Magnetism, Section 1, Christiania, Aschehoug \& Co, Kristiania, 5-9, 1908.

Brekke, A.: Haldde - arnested for den moderne nordlysforskning, Altaboka 1982, Årbok for Alta, p. 64, 1982.

Brekke, A. and Lynne Hansen, T.: The Northern Lights, Alta Musum Pamphlets No. 4, Alta Museum No. 4, Alta Museum, Alta, Norway, 1997.
Bunting, M. and Jensen, T.: Science and daily life in the study of northern lights, 1898-1928, Newcastle, Cambridge Scholars Publishing, Lady Stephenson Library Newcastle upon Tyne NE6 2PA United UK, 2018.

Devik, O.: Blant fiskere, forskere og andre folk, Aschehoug, H. Aschehoug \& CO. (W. Nygaard) Oslo, p. 32, 1971.

Dalton XIII, J.: On the height of the Aurora borealis above the surface of the earth; particularly one seen on the 29th of March, 1826, Phil. Trans. Roy. Soc. Lond., 8, p. 298, 1828.

Føyn, M. J.: Utvidelse av observatoriet paa Haldde - Stormvarsler i det nordlige Norge, Norsk Fiskeritidende, Norges Fiskeritidende Selskabet for norske Fiskeriers Fremme, Bergen, 142-150, 1915.

Friedman, R.-M.: Making the Aurora Norwegian: Science and Image in the Making of a Tradition, Interdisciplinary Science Reviews, 35, 51-68, 2010.

Fulsås, N.: Universitetet i Troms $\varnothing 25$ år, Universitetet i Troms $\varnothing$, Universitetet i Troms $\varnothing$, Troms $\varnothing, 1993$.

Høegh, T.: Troms $\varnothing$ Bys Historie, edited by: Ytreberg, N. A., Troms $\varnothing$, Vol. 3, p. 77, 1971.

Knutsen, N. M. and Posti, P.: La Recherche En ekspedisjon mot nord Une expédition vers le Nord, Angelica, TotalFinaElf Exploration AS, 138-147, 2002.

Köhler, H.: Die Untersuchungen auf dem Haldde-Observations von 1918-1920, Wien Kommissionsverlag von Julius Springer, Wien, p. 16, 1928.

Krogness, O.: Haldde - observatoriet, dets virksomhet og nogen foreløbige resultater, Naturen, Vol. 39, No. 7-8, Bergen, p. 217, 1915.

Krogness, O.: Das Haldde-Observatorium, Vol. XXXV, Jahrbericht des Sonnblick-Vereines für das Jahr 1926, Wien Kommisionsverlag von Julius Springer, 11-17, 1928.

Krogness, O.: Duplicates from the Haldde Observatory, National Archive Troms $\varnothing$, Norway, Duplication of handwritten letters by Krogness at the Haldde Observatory, 1982.

Krogness, O. and Devik, O.: Haldde-Observatoriet og dets meteorologiske arbeider, p. 130, Grøndahl \& Søn Forlag AS Kristiania, 124-138, 1917.

Lottin, V., Bravais, A., and Lilliehöök, C. B.: Voyages en Scandinavie, en Laponie, au Spitzberg et aux Feröe, pendant les années 1838, 1839, 1840 sur la corvette la Recherche, Arthus Bertrand, 265-294, 1840.

Moss, K. and Stauning, P.: Sophus Peter Tromholt: an outstanding pioneer in auroral research, Hist. Geo Space. Sci., 3, 53-72, https://doi.org/10.5194/hgss-3-53-2012, 2012.

Nielssen, R. A. and Pettersen, A.: Nordlyspionerene Menneskene og Observatoriet på Halddetoppen i Alta, Grøndahl \& Dreyers Forlag AS, Oslo, p. 27, 1993.

Störmer, C.: The Polar Aurora, Oxford at the clarendon Press, Oxford University Press, Amen House, London E.C.4, p. 38, 1955

Tromholt, S.: Under Nordlysets Straaler. Skildringer fra Lappernes Land, Gyldendalske Boghandels Forlag, Kjøbenhavn, 270-271, 1885 . 